\title{
Monocentryczne versus policentryczne prawo pracy
}

rofesor Michał Seweryński należy do wybitnych polskich teoretyków
prawa pracy o światowej renomie. W Jego twórczości wiele miejsca zajmują węzłowe problemy prawa pracy i prawa socjalnego, $\mathrm{w}$ tym kwestie dotyczące przyszłości i rozwoju obu tych gałęzi prawa. Profesor Seweryński był członkiem, a następnie Przewodniczącym Komisji Kodyfikacyjnej Prawa Pracy, która zakończyła swe prace dwoma projektami - Kodeksu pracy oraz Zbiorowego kodeku pracy. Oba projekty, pomimo że nie weszły w życie, stanowią znaczący dorobek doktryny oraz projekcję rozwoju prawa pracy. Dlatego w niniejszym opracowaniu poświęconym Szanownemu Jubilatowi chciałbym poruszyć kwestię przewidywanych kierunków ewolucji prawa pracy i prawa zatrudnienia.

1. Nie powinno chyba ulegać wątpliwości, że od samego początku prawo pracy było budowane jako system monocentryczny. Pod określeniem tym rozumiem zespół norm prawnych zintegrowanych ze sobą wedle jednolitego kryterium, jakim stał się stosunek pracy najemnej, przekształcony ostatecznie w stosunek pracy. Monocentryczność prawa pracy oznacza zatem, że w centrum tej gałęzi prawa znajduje się tylko jeden rodzaj stosunku prawnego, którego przedmiotem jest świadczenie pracy. Stosunek ten jest jednocześnie ośrodkiem integrującym całe prawo pracy. Jest ono bowiem tradycyjnie definiowane przedmiotowo jako zespól norm regulujących społeczne stosunki pracy oraz inne stosunki prawne związane ściśle (życiowo, funkcjonalnie, integralnie etc.) ze stosunkiem pracy ${ }^{1}$. Ważne jest także i to, że stosunek pracy jest konstrukcją

\footnotetext{
* Dr hab., prof. nadzw., dziekan Wydziału Prawa i Administracji i kierownik Katedry Prawa Pracy Uniwersytetu Gdańskiego.

${ }^{1}$ M. Święcicki w: Z. Salwa, W. Szubert, M. Święcicki, Podstawowe problemy prawa pracy, Warszawa 1957, s. 17; Z. Salwa, Prawo pracy i ubezpieczeń społecznych, Warszawa 1996, s. 15; T. Zieliński, Prawo pracy. Zarys systemu, t. I, Warszawa-Kraków 1986, s. 19; W. Szubert, Zarys prawa pracy, Warszawa 1980, s. 9-10; W. Jaśkiewicz w: W. Jaśkiewicz, C. Jackowiak, W. Piotrowski, Prawo pracy w zarysie, Warszawa 1985, s. 14.
} 
normatywną o jednolitym charakterze i jednolitej budowie. Możemy co prawda wyróżniać odmiany stosunku pracy, ale czyni się to zawsze poprzez stosowanie kryteriów pobocznych, a nie zasadniczych (np. kryterium podstawy nawiązania lub czasu trwania stosunku pracy). Nie ulega również wątpliwości, że koncepcja stosunku pracy zawsze występowała w otoczeniu innych konstrukcji prawnych, których przedmiotem także było wykonywanie różnych zajęć, z reguły zarobkowych, które obecnie określa się zbiorczo mianem „zatrudnienia”. Przede wszystkim wymienić tu należałoby umowy (i stosunki prawne) cywilnoprawne, związane z wykonywaniem określonych czynności czy usług, a także stosunki służby w sferze publicznej.

Stosunek pracy najemnej, mający rodowód cywilnoprawny, szybko stał się zalążkiem nowego podsystemu normatywnego, którego celem było stworzenie ram prawnych dla masowo narastającego zjawiska pracy najemnej. Oczywiście początkowo chodziło o wydzielenie się takiego podsystemu $\mathrm{w}$ ramach prawa cywilnego. Przez wiele dziesiątków lat prawo pracy (zwane prawem robotniczym czy fabrycznym) traktowano jako część prawa cywilnego z elementami ochrony udzielanej przez państwo. Dopiero rozwój regulacji ochronnych o charakterze publicznym, z równoczesnym uznaniem przez państwo roli i znaczenia porozumień zbiorowych zawieranych przez związki zawodowe z pracodawcami, doprowadziły $\mathrm{w}$ istocie do wyodrębnienia się w systemie prawa nowej gałęzi, zwanej powszechnie prawem pracy. Niewątpliwie duży wpływ na to miały przemiany charakteru prawnego stosunku pracy najemnej. Jak już wcześniej wspomniano, miał on początkowo charakter cywilnoprawny. Jego istotą było wynajęcie (,sprzedanie”) przez robotnika swojej pracy na rzecz pracodawcy. Praca była więc traktowana jak każdy inny towar na rynku, podlegała wycenie $\mathrm{z}$ uwzględnieniem reguł nieskrępowanej wymiany towarowej, a praktycznie jedynym miernikiem tej wyceny była wolna gra rynkowa pomiędzy zapotrzebowaniem na pracę ze strony pracodawcy (podaż) oraz liczbą chętnych do pracy (popyt). Jakiekolwiek czynniki o charakterze społeczno-bytowym nie były brane pod uwage lub schodziły na dalszy plan. Dopiero rozbudowa regulacji ochronnych zarówno pochodzenia państwowego, jak i wywalczonych przez organizacje reprezentujące interesy robotników, doprowadziły do zmiany postrzegania istoty stosunku pracy najemnej, „oderwania” tego stosunku z prawa cywilnego i poddania go regulacjom nowej gałęzi prawa. Nasycenie stosunku pracy najemnej pierwiastkami ochronnymi, ukierunkowanymi na wzmocnienie pozycji osoby zatrudnionej, musiało też osłabić „towarowy" charakter tego stosunku, praca przestała być już zwykłym towarem, oderwanym od wykonawcy. Wprowadzenie regulacji chroniących życie, zdrowie i interesy pracowników, nasycenie stosunku pracy świadczeniami 
pracodawcy nie pozostającymi w bezpośrednim związku z wykonywaną praca, przekształciło „najem pracy” w stosunek prawny o odmiennym charakterze, który można już było określać mianem „najmu pracownika”.

Zerwanie bezpośredniej więzi najmu pracy, przekształconego ostatecznie $\mathrm{w}$ najem pracownika, $\mathrm{z}$ prawem cywilnym pozostawiło $\mathrm{w}$ tym ostatnim pewną lukę, która tylko częściowo została zapełniona przez inną konstrukcję normatywną jaką jest „najem usług”. Wydaje się, że określenie to pasuje do niektórych umów cywilnoprawnych, takich jak umowa zlecenia, umowa o świadczenie usług czy umowa o dzieło. Przedmiot zobowiązania w tych umowach jest wyznaczony dość wąsko, są nim określone czynności prawne lub faktyczne albo określone dzieło, a nie szeroko rozumiana praca. Tym samym nastąpiło wyraźne rozgraniczenie pomiędzy „najmem pracownika” (stosunkiem pracy) a "najmem usług” (stosunki cywilnoprawne) wedle kryterium przedmiotu zobowiązania. Dla stosunku pracy jest nim praca określona rodzajowo, dla stosunku cywilnoprawnego - usługa określona parametrem czynności prawnej lub faktycznej albo dzieła.

Owo rozgraniczenie otworzyło drogę do wyodrębnienia nowej gałęzi prawa ze stosunkiem pracy jako konstrukcją prawną otoczoną powiązanymi z nią innymi stosunkami prawnymi. Zakresem tej gałęzi prawnej objęte są normy prawne (państwowe i autonomiczne), które regulują te stosunki. W rezultacie po emancypacji prawa pracy w systemie prawnym kwestie dotyczące zatrudnienia zależnego obejmowały aż trzy formalnie równorzędne gałęzie prawa - prawo pracy, prawo cywilne oraz prawo administracyjne (publiczne). To ostatnie regulowało tzw. stosunki służbowe nawiązywane przez państwo z jego funkcjonariuszami. Wymienione trzy gałęzie prawa odgrywały jednak niejednakową rolę w systemie prawnej reglamentacji zatrudnienia. Przede wszystkim jedynie prawo pracy nastawione było w całości na „obsługę” prawną określonego rodzaju zatrudnienia, podczas gdy dla prawa cywilnego i administracyjnego zagadnienia te stanowiły tylko fragment ich przedmiotu. Prawo pracy w krótkim czasie zaczęło odgrywać dominującą rolę w regulacji zatrudnienia, przynajmniej w sferze prywatnego przemysłu i usług. Rola prawa cywilnego miała tu wyraźnie uzupełniający i poboczny charakter.

Występowanie $\mathrm{w}$ systemie prawnym trzech autonomicznych podsystemów regulacji zatrudnienia nie oznaczało, iż pomiędzy nimi nie zachodziły żadne związki. Silne powiązania występowały zwłaszcza między prawem cywilnym i prawem pracy ze względu na ich genetyczne związki (zdecydowana większość instytucji prawa pracy, z umową o pracę na czele, ma rodowód cywilnoprawny).

2. Zarysowany wyżej układ prawa dotyczącego zatrudnienia, oparty na dominującej pozycji prawa pracy, trwał w niemal niezmienionej postaci przez cały wiek XX. Sprzyjała mu bowiem specyfika masowego zatrudnienia 
w wielkich zakładach produkcyjnych, które to zjawisko wraz z towarzyszącymi mu uwarunkowaniami społecznymi i ekonomicznymi określa się niekiedy - od nazwiska jednego z wielkich przemysłowców - mianem fordyzmu. Dla zjawiska tego charakterystyczne było masowe zatrudnienie, w jednej fabryce zatrudniano kilkuset lub nawet kilka tysięcy robotników, ich praca miała powtarzalny i wąsko specjalistyczny charakter, wreszcie ważne znaczenie miała także stabilność zatrudnienia gwarantowana w długich okresach dynamicznego rozwoju przedsiębiorstw. Jednocześnie system ten sprzyjał silnym i dobrze zorganizowanym organizacjom reprezentującym interesy pracowników. Miały one charakter masowy, cieszyły się dużym poparciem załóg zakładów pracy. To właśnie na wiek XX przypadł rozkwit ruchu związkowego, który nie tylko przyczynił się do zwiększenia poziomu uprawnień pracowniczych, ale także uzyskał instytucjonalne i prawne (nierzadko konstytucyjne) gwarancje wpływu na sprawy publiczne.

Ukształtowany pod koniec XIX w. model prawnej reglamentacji pracy podporządkowanej (najem pracy, najem pracownika) odpowiadał potrzebom właścicieli fabryk, którzy gotowi byli na daleko idące ustępstwa na rzecz świata pracy za cenę spokoju przy prowadzeniu działalności. Jak się zresztą okazało, poprawa warunków zatrudnienia, w tym systematyczny wzrost płac, doprowadziła do zwiększenia popytu wewnętrznego na oferowane przez przemysłowców różnego rodzaju dobra i usługi. Według wspomnianego już wyżej potentata przemysłu samochodowego i jednego z największych wizjonerów ówczesnych czasów Henrego Forda, produkowane przez niego samochody powinny być dostępne także dla zatrudnianych przez niego robotników ${ }^{2}$. Symbolem nowego sposobu gospodarowania była upowszechniona przez Forda taśma produkcyjna, doskonale sportretowana w znanym filmie Dzisiejsze czasy z 1936 r. przez innego wielkiego wizjonera i geniusza kina Charliego Chaplina. Taśma produkcyjna nie tylko znacznie zwiększyła wydajność pracy, ale także przyczyniła się do zmiany jej organizacji. Każdy robotnik miał ściśle przypisaną sobie rolę $\mathrm{w}$ procesie produkcji i określone miejsce $\mathrm{w}$ hierarchii społeczności zakładowej, poddany był także ścisłej kontroli i nadzorowi ze strony przełożonych. Jednocześnie okres niebywałej prosperity w krajach zachodnich w wieku XX (z przerwami w okresie wojen światowych i wielkiego kryzysu lat trzydziestych) utrwalił też model zatrudnienia opartego na stabilizacji i poczuciu bezpieczeństwa socjalnego robotników. W ten sposób model zatrudnienia opartego na stosunku pracy najemnej spełniał oczekiwania nie tylko świata pracy, ale także w znacznej mierze odpowiadał pracodawcom, nie było więc powodu do poszukiwania czy konstruowania nowych rozwiązań prawnych z tej dziedziny.

${ }^{2}$ J. Rifkin, Koniec pracy. Schyłek siły roboczej na świecie i poczatek ery postrynkowej, Wrocław 2003, s. 41. 
Podobnie sytuacja wyglądała $\mathrm{w}$ krajach tzw. bloku wschodniego, gdzie powstawanie wielkich zakładów przemysłowych wiązało się $\mathrm{z}$ uwarunkowanym ideologicznie dążeniem do stworzenia klasy robotniczej, a w dalszej kolejności - nowego społeczeństwa komunistycznego. Prawo pracy postrzegano przy tym nie tylko jako instrument prawnej reglamentacji zatrudnienia, ale przede wszystkim jako przejaw postępu, namacalny wyraz poprawy losu klasy robotniczej. Rozwiązania socjalne ukazywano jako jedną ze zdobyczy ludu pracującego, uzyskaną wyłącznie dzięki nowej władzy i nowemu porządkowi społecznemu. Pod hasłem "każdemu według jego potrzeb, od każdego według jego możliwości" likwidowano (oczywiście tylko w teorii) nieuzasadnione ideologicznie odrębności statusu zatrudnionych. Tym m.in. tłumaczyć należy typowe dla państw socjalistycznych upowszechnianie zatrudnienia pracowniczego (umów o pracę) w sferze publicznej, a więc odchodzenie od reżimu zatrudnienia publicznoprawnego ${ }^{3}$. W Polsce proces ten doprowadził - pod hasłem egalitaryzmu społecznego - do całkowitego zniesienia odrębności prawa urzędniczego i włączenia go w całości do prawa pracy (w latach 1975-1982). Jedynie stanowiący oparcie dla władzy aparat bezpieczeństwa państwowego (wojsko, milicja, służba bezpieczeństwa) zachował przywileje wynikające $\mathrm{z}$ dotychczasowego statusu. Co prawda po doświadczeniach kryzysu społeczno-politycznego po sierpniu 1980 r. władze zdecydowały się na przywrócenie rozwiązań szczególnych obejmujących zatrudnienie w aparacie administracyjnym, jednak nowo uchwalona pragmatyka pracowników urzędów państwowych z 1982 r. oparta już była na koncepcji stosunku pracy, a nie stosunku służbowego. Także przemiany społeczno-polityczne przełomu lat osiemdziesiątych i dziewięćdziesiątych XX w. nie zmieniły obranej wcześniej drogi. Wszystkie pragmatyki urzędnicze w Polsce uchwalone po $1989 \mathrm{r}$. miały już charakter pracowniczy. Trzeba jednak odnotować, że podobne zjawisko, choć na dużo mniejszą skalę, wystąpiło także w krajach Europy Zachodniej. Niektóre uprawnienia o charakterze pracowniczym przenikały stopniowo do statusu funkcjonariuszy publicznych. Najbardziej widoczne było to w obszarze praw związkowych i wolności koalicji. Jednak ta swoista „laboryzacja” służby publicznej nie doprowadziła jak dotąd do zatarcia różnic pomiędzy reżimami zatrudnienia pracowniczego i publicznoprawnego ${ }^{4}$.

${ }^{3} \mathrm{~W}$ istocie przyczyny zniesienia odrębności prawa urzędniczego było inne. Chodziło przede wszystkim o usunięcie z korpusu urzędniczego osób niewygodnych i nasycenie aparatu państwowego ludźmi z awansu społecznego. Z tego punktu widzenia rozwiązania prawa pracy były o wiele bardziej użyteczne, aniżeli publicznoprawne prawo urzędnicze z zasadą trwałości zatrudnienia i wysokimi cenzusami wykształcenia.

${ }^{4}$ M. Sānchez Morón, Derecho de la función pública, Madrid 2013, s. 18. 
3. Utrwalany przez większą część XX w. model prawnej reglamentacji zatrudnienia, oparty na dominacji koncepcji stosunku pracy dobrowolnie podporządkowanej (najmu pracownika) z coraz większym trudem wytrzymywał konfrontację z nasilającymi się już od ponad czterdziestu lat nowymi zjawiskami w gospodarce. Pomijając już cykliczne kryzysy (np. wielki kryzys naftowy z początku lat siedemdziesiątych czy kryzysy bankowo-finansowe z lat dziewięćdziesiątych i ostatni z roku 2008) dotykające nie tylko poszczególnych państw, ale także całych regionów, zaobserwować możemy obecnie coraz bardziej postępującą ekonomizację procesów gospodarczych. Oczywiście dążenie do maksymalizacji zysku jest naturalną cechą działalności gospodarczej, jednak w ostatnich dziesiątkach lat przybiera ona nie tylko niespotykane dotąd rozmiary, ale wręcz niekiedy absurdalną postać (np. celowe produkowanie towarów o obniżonej trwałości, po to, by napędzać popyt w bliskiej przyszłości). Wiązać to należy zarówno $\mathrm{z}$ globalizacją dotykającą prawie wszystkich sfer naszego życia i wynikającym z niej znoszeniem barier w kontaktach pomiędzy państwami i regionami świata (a co za tym idzie wzrostem konkurencyjności transgranicznej i transregionalnej), jak również z dynamicznym rozwojem nowoczesnych technologii, technik zarządzania i organizowania procesów pracy. Ogromny wzrost wydajności pracy prowadzi do stanu, kiedy coraz mniej ludzi potrzeba do wyprodukowania i dostarczenia na rynek coraz większej puli produktów i usług za coraz niższą cenę. Dlatego dobra niegdyś luksusowe (samochody, sprzęt elektroniczny, podróże, ale także dostęp do edukacji etc.) są w zasięgu ręki przeciętnego konsumenta w Europie czy Ameryce. Jednocześnie dysproporcje w poziomie życia i dochodów pomiędzy regionami świata skłaniają wielu przedsiębiorców do lokowania działalności biznesowej poza miejscem sprzedaży swoich produktów, a więc tam, gdzie ich wytworzenie jest tańsze. Obrazu dopełnia katastrofalna sytuacja demograficzna, problemy z adaptacją imigrantów oraz pogarszający się stan finansów poszczególnych państw i towarzyszący mu nadmierny fiskalizm.

W takich warunkach trudno byłoby oczekiwać, że agresywna ekonomizacja ominie sferę prawa. Konkurencja wymusza na pracodawcach poszukiwanie tańszych aniżeli najem pracownika (stosunek pracy) rozwiązań prawnych, oferowane dotąd zatrudnienie pracownicze staje się zbyt drogie, zwłaszcza jeśli zestawimy je z półniewolniczą pracą w słabiej rozwiniętych regionach świata. Podnosi się zatem postulat odchodzenia od nadmiernych obciążeń socjalnych, które dławią konkurencyjność gospodarek krajów wysoko rozwiniętych. Coraz większego znaczenia nabierają nietypowe i elastyczne formy zatrudnienia, w tym umowy cywilnoprawne. Ich główną zaletą jest to, że pozwalają one na osłabianie mechanizmów ochrony socjalnej przewidzianej przez prawo pracy, 
a w przypadku umów cywilnoprawnych możliwe jest nawet całkowite wyłączenie się spod reżimu zatrudnienia pracowniczego.

Fenomen popularności umów cywilnoprawnych wynika jednak nie tylko z tego, że dzięki nim pracodawcy unikają wielu obciążeń o charakterze socjalnym i publicznoprawnym, ale także z tego, że umowy te są promowane jako lepiej dostosowane do wymagań współczesności. Jak się niekiedy podnosi, dzisiejszy pracownik niewiele ma już wspólnego z dawnym robotnikiem, w dobie nowoczesnych technologii większe znaczenie przypisuje się raczej kreatywności i swobodzie twórczej. Powszechny dostęp do edukacji, także na poziomie ponadpodstawowym i wyższym, sprawia, że rosną kwalifikacje formalne pracowników, a przez to także ich aspiracje i oczekiwania. Prawie nikt już nie chce być robotnikiem, a rzesze osób legitymujących się dyplomami szkół średnich i wyższych oczekują ofert zatrudnienia odpowiadających ich wykształceniu. Zresztą pracodawcy często pozornie spełniają te oczekiwania dostosowując do nich nomenklaturę stanowisk (np. kasjer staje się „menadżerem” lub co najmniej „opiekunem klienta”, a sprzątaczka - „konserwatorem powierzchni poziomej”). Powoli zanika znany podział ludzi pracy na "białe” i "niebieskie” kołnierzyki, pojawia się nowa kategoria - „krzemowe kołnierzyki", oznaczająca osoby o wysokich kwalifikacjach, obsługujące „inteligentne” maszyny, zastępujące robotników ${ }^{5}$. Zmienia się też struktura zakładów pracy, wielkie fabryki ustępują miejsca z jednej strony dużej liczbie małych i średnich podmiotów gospodarczych, w których zatrudnienie znajduje 70-80\% osób czynnych zawodowo, z drugiej zaś strony pojawiają się wielkie koncerny o zasięgu globalnym, które lokalizują swoje oddziały produkcyjne w atrakcyjnych kosztowo regionach świata i które stają się równorzędnym albo nawet silniejszym partnerem dla części państw. Dlatego w takich warunkach dość sztywna konstrukcja stosunku pracy, opartego na organizacyjnym podporządkowaniu pracownika, jest postrzegana jako przestarzała, jako relikt epoki kapitalizmu wielkoprzemysłowego i hamulec rozwoju.

Nie powinno raczej ulegać wątpliwości, że prawdziwym powodem przechodzenia przez pracodawców na umowy cywilnoprawne są względy oszczędnościowe. Zarzucane konstrukcji zatrudnienia pracowniczego wady odnoszą się jedynie do niewielkiej części osób żyjących z własnej pracy, a tymczasem są one przytaczane jako argument na rzecz rozwiązań powszechnych. Jednak bez względu na ocenę tego zjawisko nie ulega wątpliwości, że jest ono faktem i to przybierającym coraz większe rozmiary.

Zwiększenie się liczby osób, dla których kontrakty cywilne stały się jedyną lub dominującą podstawą zatrudnienia, zmienia w sposób zasadniczy obraz współczesnego świata pracy. Ale przecież prawo cywilne

${ }^{5}$ J. Rifkin, Koniec pracy..., s. 178 i nast. 
z trudem jest w stanie udźwignąć ciężar regulacji pracy najemnej o znacznych rozmiarach. Jest ono w dalszym ciaggu nastawione na "najem usług”, nie daje zatem prawie żadnej ochrony prawnej i socjalnej wzrastającej liczbie osób formalnie świadczących usługi, a w istocie wykonujaccych pracę. Co prawda zasada swobody kształtowania treści umowy i stosunku prawnego daje - teoretycznie - możliwość ukształtowania wzajemnej pozycji stron umowy cywilnoprawnej analogicznie do tego, co wynika z przepisów prawa pracy, ale w praktyce rzadko kiedy tak się dzieje. Nierównowaga pomiędzy stronami takich umów jest przecież taka sama albo nawet większa, niż stron stosunku pracy. W mniejszym stopniu wykonawcy usług korzystają z praw związkowych, formalnie w Polsce osoby takie nadal nie posiadają prawa koalicji (pomimo stanowiska Komitetu Wolności Związkowej Międzynarodowej Organizacji Pracy z 2012 r. zalecającego naszemu krajowi zmianę prawa $w$ tym zakresie $\left.{ }^{6}\right)$. A to przecież właśnie dążenie do osłabienia tej dysproporcji legło u podstaw interwencjonizmu państwowego i wprowadzenia norm chroniących życie, zdrowie $\mathrm{i}$ interesy pracowników. Normy te wyodrębniono następnie z prawa cywilnego, nadając im rangę osobnej gałęzi prawa. Upowszechnienie zatrudnienia cywilnoprawnego i odchodzenie od prawa pracy oznacza, że historia zatoczyła koło. Rodzi się więc pytanie, czy ponownie stajemy przed obliczem tych samych problemów społecznych, z którymi zmagaliśmy się już sto kilkadziesiąt lat temu, i które rozwiązaliśmy m.in. dzięki ochronnemu prawu pracy.

Wydaje się, że możliwe są tu różne scenariusze, przy czym prosta replikacja zdarzeń sprzed wielu lat jest tylko jednym $\mathrm{z}$ nich, $\mathrm{z}$ uwagi na nowy kontekst społeczny i polityczny - raczej mało prawdopodobnym. Być może nie grozi nam już rewolucja społeczna, ale z pewnością realne są inne zagrożenia, których źródłem jest odchodzenie od prawa pracy i rozpowszechnienie jako podstawy zatrudnienia umów cywilnoprawnych, zwanych w Polsce dosadnie umowami „śmieciowymi” (np. problem masowego wykluczenia społecznego, emigracji czy katastrofa demograficzna). Z pewnością państwo powinno dokonać zasadniczej rewizji swojej polityki społecznej.

4. Opisywane zjawiska mają też oczywiście duży wpływ na system prawny. To m.in. poprzez prawo są lub powinny być wprowadzane określone instrumenty z zakresu polityki społecznej. Warto w szczególności zwrócić uwagę na kwestie systemowe. Jak wcześniej wspomniano, zmienia się obraz systemu prawa regulującego zatrudnienie. Pozycję równorzędną prawu pracy i prawu administracyjnemu (służbowemu) zyskuje

${ }^{6}$ Szerzej na ten temat E. Podgórska-Rakiel, Szczególna ochrona trwałości zatrudnienia działaczy zwiazkowych pozostajacych w zatrudnieniu cywilnoprawnym - uwagi de lege lata $i$ de lege ferenda, [w:] Zwiąkowe przedstawicielstwo pracowników zakładu pracy, red. Z. Hajn, Warszawa 2012, s. 578 i nast. 
w wielu państwach prawo cywilne. Nie można dłużej utrzymywać, że cywilnoprawny reżim zatrudnienia ma wciąż charakter uzupełniający i poboczny względem reżimu pracowniczego. Ale przecież w płaszczyźnie aksjologicznej i konstrukcyjnej niewiele się zmieniło, $\mathrm{w}$ dalszym ciągu jedynie prawo pracy (a prawo służbowe w sferze publicznej) zapewnia dostateczny poziom ochrony prawnej i socjalnej osobom zatrudnionym. Co więcej nadal istnieją przepisy, które przewidują wyłączną właściwość konstrukcji stosunku pracy w przypadku wykonywania pracy podporządkowanej. Granice pomiędzy reżimami prawnymi zatrudnienia pracowniczego, cywilnoprawnego i służbowego, oparte na parametrze „,szerokości" przedmiotu powinności osób zatrudnionych (praca, usługi i służba) nie zostały na drodze prawnej zakwestionowane. Jednak coraz większym problemem staje się nieprzestrzeganie obowiązującego prawa, państwo nie jest w stanie lub - co gorsza - niekiedy nie chce skutecznie reagować na pojawiające się nieprawidłowości w tej dziedzinie.

Jaka zatem przyszłość czeka prawo pracy? Zakładając, że konieczne są zmiany natury systemowej, można pokusić się o nakreślenie pewnych scenariuszy. Wydaje się przy tym, że głównym problemem wymagającym rozstrzygnięcia będzie zarysowany w tytule niniejszego opracowania dylemat dotyczący charakteru prawa pracy. Jest ono ukształtowane jako system monocentryczny z jedną wiodącą i integrującą tę gałąź prawa konstrukcją normatywna, jaką jest stosunek pracy podporządkowanej. Obok prawa pracy największe znaczenie $\mathrm{w}$ regulowaniu stosunków zatrudnienia mają prawo administracyjne ze stosunkiem służbowym oraz prawo cywilne ze stosunkami prawnymi, dla których źródłem są umowy o świadczenie usług (m.in. umowa zlecenia, na warunkach umowy zlecenia oraz umowa o dzieło). W efekcie w systemie prawa współegzystują trzy autonomiczne podsystemy ukierunkowane na regulację zatrudnienia.

Należy jednak wyraźnie zastrzec, że - jak już wcześniej wspomniano - duża liczba umów cywilnoprawnych związanych z wykonywaniem zatrudnienia jest zawierana $w$ sytuacjach, kiedy prawo wymaga zawarcia umowy o pracę. Chodzi tu o przypadki wykonywania pracy w warunkach podporządkowania organizacyjnego. Tymczasem o prawnej kwalifikacji danej umowy czy stosunku prawnego decyduje ich treść i sposób wykonywania, a nie nadana przez strony nazwa. Potwierdzenie tej zasady znajdujemy zarówno w kodeksie cywilnym (art. 65 §), jak i w kodeksie pracy (art. $22 \S 1^{1}$ ). Motywem skłaniającym pracodawców do oferowania umów cywilnoprawnych w miejsce umów o pracę są względy ekonomiczne, kandydaci do pracy godzą się natomiast na przyjęcie takich propozycji pracodawców, bo to często jedyna szansa na podjęcie jakiegokolwiek zajęcia zarobkowego (zgodnie z hasłem "lepsza taka praca niż żadna”). Dodatkowym czynnikiem jest de facto postawa (cichego) przyzwolenia państwa na taką praktykę. 
Z punktu widzenia zadań polityki społecznej państwa ważne jest to, że zatrudnieni na podstawie umów cywilnoprawnych nie tworzą jednolitej grupy. Wydaje się celowe wyróżnienie co najmniej trzech ich grup. W pierwszej znajdują się wskazane wyżej osoby nieprawidłowo pozostające $\mathrm{w}$ zatrudnieniu cywilnoprawnym. Osoby te ze względu na warunki wykonywania pracy mają $w$ istocie status pracowniczy, lecz $\mathrm{z}$ tego statusu $\mathrm{z}$ różnych powodów nie korzystają (tzw. pozorni usługodawcy). W drugiej grupie umieścić należy tych usługobiorców, którzy zawarli „prawidłowe" umowy cywilnoprawne, ale ze względu na swoje położenie (np. ekonomiczną zależność od jednego podmiotu) ich sytuacja zbliżona jest do pracowniczej (tzw. parapracownicy). I wreszcie w ostatniej grupie znajdują się osoby, dla których usługi wykonywane w ramach umów cywilnoprawnych stanowią działalność poboczną (uzupełniająca) lub też wynikają ze specyfiki wykonywanego zawodu (np. przedstawiciele tzw. wolnych zawodów). Nie ulega wątpliwości, że jedynie sytuacja osób zaliczonych do dwóch pierwszych grup stwarza problemy dla polityki społecznej państwa.

5. Rodzi się zatem pytanie, czy i ewentualnie w jakim stopniu wymienione wyżej osoby, zatrudnione $\mathrm{w}$ reżimie cywilnoprawnym, powinny być objęte jakimś systemy ochrony socjalnej. Chodzi tu zwłaszcza o owych pozornych usługodawców i parapracowników. Szczególnie sytuacja tych pierwszych jest dość oczywista, w istocie bowiem „wyjęcie” ich z prawa pracy ma charakter patologiczny, włączenie zaś tej grupy do tego prawa oznaczałoby przywrócenie stanu zgodności z prawem. Wymagałaby to zmiany postawy ze strony państwa i jego organów kontrolnych, a być może także udoskonalenia przepisów wymuszających przestrzeganie prawa.

Sytuacja parapracowników jest pod tym względem bardziej skomplikowana. Wydaje się jednak, że istnieją co najmniej dwa powody, dla których również oni winni być objęci jakimś systemem ochrony socjalnej. Przede wszystkim uzasadnia to ich sytuacja faktyczna, dotykają ich bowiem te same problemy społeczne, co pracowników. Oczywiście, ze względu na specyfikę ich zatrudnienia, mniejszą zależność organizacyjną od pracodawców, a przez to większy zakres swobody, nie wchodzi w grę rozszerzenia na te osoby wszystkich regulacji prawa pracy. Ponadto przytoczyć tu można argumenty natury konstytucyjnej, w tym przede wszystkim zasadę równości i zakazu dyskryminacji. Całkowite pozbawienie ochrony parapracowników można postrzegać jednak jako pogwałcenie tych zasad ${ }^{7}$.

7 A. Sobczyk, Prawo pracy w świetle Konstytucji RP, t. I, Teoria publicznego i prywatnego indywidualnego prawa pracy, Warszawa 2013, s. 65 i nast. 
Spośród wszystkich możliwych dróg rozwiązania zarysowanego problemu należałoby z pewnością odrzucić dwie skrajne, tzn. rozszerzenie w całości i bez wyjątków zakresu prawa pracy na wszystkich zatrudnionych bądź też pozostawienie obecnej sytuacji bez żadnych zmian. Nie ulega wątpliwości, że rozwiązania te nie mogą być wprowadzone - pierwsze $\mathrm{z}$ nich oznaczałoby nadmierne usztywnienie reglamentacji prawnej zatrudnienia, drugie natomiast niebezpiecznie przybliża prawo pracy do tzw. miękkiego prawa (soft law), stosowanego na zasadzie faktycznej dobrowolności.

$\mathrm{W}$ istocie więc należy rozważyć rozwiązania pośrednie. Wydaje się celowe podjęcie działań polegających na:

1) wzmocnieniu skuteczności obowiązujących regulacji prawnych - należy więc dążyć do wyeliminowania patologii wynikającej z nadużywania umów cywilnoprawnych. Jeśli prawo wyraźnie delimituje reżimy zatrudnienia przewidując poddanie prawu pracy stosunków pracy podporządkowanej, to od instytucji państwa winno się wymagać stworzenia rozwiązań zapewniających przestrzeganie prawa;

2) objęciu parapracowników mniej lub bardziej rozbudowanym systemem ochrony socjalnej. Nie chodziłoby oczywiście o zrównanie ich praw z pracownikami, lecz o wprowadzenie pewnych elementów ochronnych częściowo wzorowanych na rozwiązaniach prawa pracy. Teoretycznie wyobrazić tu sobie można dwie możliwości. Pierwsza z nich to częściowe włączenie parapracowników do prawa pracy, druga - uzupełnienie regulacji prawa cywilnego o przepisy ochronne ${ }^{8}$. W pierwszym przypadku stosunki zatrudnienia parapracowników nie byłyby stosunkami pracy, lecz innymi stosunkami zatrudnienia regulowanymi przez prawo pracy. Wydaje się, że w takim kierunku zmierzali autorzy projektu nowego kodeksu pracy przygotowanego przez komisję kodyfikacyjną prawa pracy, której przewodniczył Szanowny Jubilat Profesor Michał Seweryński. W księdze siódmej tego projektu znalazły się bowiem propozycje dotyczące zatrudnienia niepracowniczego, które obejmują dwie grupy - zatrudnionych na podstawie umowy oraz osoby piastujące kierownicze stanowiska państwowe. Wszyscy oni byliby objęci pewnymi elementami ochrony socjalnej, wzorowanymi częściowo na ochronie pracowniczej. Jednocześnie $\mathrm{w}$ projekcie zaproponowano kryteria uznawania za parapracowników. Zgodnie z art. 462 projektu przepisy tytułu 1 księgi siódmej

${ }^{8}$ Oba rozwiązania są $\mathrm{w}$ pewnym minimalnym zakresie już stosowane $\mathrm{w}$ polskim systemie prawnym. Przykładowo wskazać tu można nakładców, którzy od połowy lat siedemdziesiątych praktycznie korzystają z niemal identycznej jak pracownicy ochrony socjalnej, oraz osoby wykonujące pracę na podstawie umowy agencyjnej, wobec których kodeks cywilny przewiduje pewne elementy ochrony podobnej do pracowniczej (np. okresy wypowiedzenia). 
kodeksu stosuje się do pracy osoby zatrudnionej na podstawie umowy innej niż umowa o pracę, wykonującej osobiście na rzecz jednego zatrudniającego pracę o charakterze ciągłym lub powtarzającym się za wynagrodzeniem przekraczającym połowę wynagrodzenia minimalnego ustalonego na podstawie odrębnych przepisów. Przepisy te znajdują zastosowanie także w razie wykonywania pracy na rzecz zatrudniającego, od którego osoba zatrudniona uzyskuje większą część wynagrodzenia, jeśli przekracza ono połowę minimalnego wynagrodzenia za pracę. Osobistego charakteru pracy nie wyłącza korzystanie przez osobę zatrudnioną z pomocy członków rodziny pozostających z nią we wspólnym gospodarstwie domowym;

3) być może konieczna byłaby także racjonalizacja samego prawa pracy. W takich państwach, jak Polska, które przeszły gruntowną transformację ustrojowa, $\mathrm{w}$ dalszym ciągu system prawa stanowi swoisty melanż rozwiązań prawnych pochodzących z różnych okresów, w tym także sprzed 1989 r. Kodeks pracy z 1974 r., pomimo wielu gruntownych nowelizacji, w dalszym ciągu oparty jest na założeniach konstrukcyjnych z czasów realnego socjalizmu. Trudno się zatem dziwić zarzutom, zwłaszcza ze strony pracodawców, że prawo pracy wymaga reformy.

6. Jak widać dotychczasowe rozważania pozostają $w$ bezpośrednim 346 związku z kierunkami rozwoju i charakterem współczesnego prawa pracy. Może ono przybrać różne formy systemu monocentrycznego lub policentrycznego.

Monocentryczne prawo pracy - jak już wcześniej wspomniano - oparte jest na koncepcji jednej centralnej konstrukcji prawnej, jaką jest stosunek pracy. Przedmiotem tak rozumianego prawa pracy są normy prawne regulujące stosunki pracy i inne stosunki z nimi związane. W tradycyjnym ujęciu monocentryczne prawo pracy jest jedną z kilku gałęzi prawa mających za swój przedmiot stosunki zatrudnienia. Inne niż stosunek pracy stosunki zatrudnienia podlegają - tak jak do tej pory - prawu administracyjnemu (stosunki służbowe funkcjonariuszy) oraz prawu cywilnemu (stosunki prawne nawiązywane w drodze umów cywilnoprawnych). Należy jednak mieć świadomość, że zakres normowania poszczególnych gałęzi prawa zależy od przyjętego modelu zatrudnienia i koncepcji stosunku pracy. Widać to bardzo wyraźnie na przykładzie zatrudnienia w służbie państwowej - jeszcze siedemdziesiąt lat temu wszyscy funkcjonariusze, urzędnicy i inne osoby wykonujące pracę na rzecz państwa pozostawali w stosunkach służbowych i nie podlegali w ogóle prawu pracy. Obecnie zaś w stosunkach służbowych pozostają wyłącznie funkcjonariusze służb zmilitaryzowanych, natomiast inne osoby zatrudnione w sferze publicznej (nauczyciele, urzędnicy etc.) mają status pracowników w rozumieniu prawa pracy. 
Powstaje pytanie, czy ekspansja prawa pracy poprzez „wchłanianie” przez stosunek pracy kolejnych grup niepracowniczych obecnie stosunków zatrudnienia, ma swoje granice. Czy dla osób o tak różnym statusie, jak funkcjonariusze służb państwowych i usługodawcy (parapracownicy), jest miejsce w ramach tej samej konstrukcji prawnej stosunku pracy. Prima facie wydaje się to niemożliwe, bo musiałoby prowadzić do dość radykalnej zmiany konstrukcji prawnej stosunku pracy i nadaniu mu w pewnym sensie zbiorczego charakteru. Warto jednak zwrócić uwagę, że pewne próby takiego podejście możemy zaobserwować już obecnie. $Z$ jednej strony służy temu postulowana zmiana kryteriów podporządkowania (z organizacyjnego na ekonomiczne $\left.{ }^{9}\right)$, z drugiej strony pewien wpływ wywierają procesy integracyjne. Wydaje się bowiem, że taką koncepcję „zbiorczego stosunku pracy" - przynajmniej częściowo - wprowadza się w prawie pracy Unii Europejskiej. Prawo to operuje pojęciem pracownika i stosunku pracy, pomimo że pojęcia te są różnie definiowane w prawodawstwie poszczególnych państw. To do kompetencji wewnętrznych Państw Członkowskich należy ustalenie zakresu zatrudnienia pracowniczego, które jest charakteryzowane za pomocą przyjętych w tych państwach kryteriów. Najczęściej kryteria te są zbieżne, z reguły na czoło wysuwa się tu podporządkowanie organizacyjne pracownika. Nie wyklucza to jednak sytuacji, kiedy określone przesłanki szczegółowe uznawania danej osoby za pracownika, będą w różnych państwach odmienne. W konsekwencji może zdarzyć się, i tak się dzieje, że osoba uznawana za pracownika w jednym państwie, w innym może pozostawać w zatrudnieniu o charakterze cywilnoprawnym lub służbowym. Zadaniem prawodawcy unijnego, który konstruuje określone standardy ochrony, jest jednak to, by w sprawach o zasadniczym charakterze przyjąć jakieś jednolite rozwiązania. Dlatego $\mathrm{w}$ doktrynie podejmowane są próby skonstruowania tzw. transgranicznego stosunku pracy, który można jednolicie rozumieć we wszystkich systemach krajowych państw członkowskich Unii Europejskiej ${ }^{10}$. Koncepcja transgranicznego stosunku pracy przenika następnie do krajowych systemów prawnych. Jako przykład może tu posłużyć sytuacja prawna niektórych funkcjonariuszy państwowych. W Polsce są oni objęci reżimem zatrudnienia służbowego, podczas gdy w świetle unijnej dyrektywy o niektórych aspektach czasu pracy należy ich uznawać za pracowników ${ }^{11}$.

Z kolei policentryczne prawo pracy zakłada wielość stosunków zatrudnienia regulowanych tą gałęzią prawa - obok tradycyjnego stosunku

9 A. Supiot, Beyond Employment. Changes in Work and the Future of Labour Law in Europe, Oxford 2001, s. 14-16.

${ }_{10}$ M. Tomaszewska, Prawo integracji stosunku pracy. Między jednościa a różnorodnościa, Gdańsk 2011, s. 148 i nast.

${ }^{11}$ Ibidem, s. 302 i nast. 
pracy podporządkowanej możliwe byłoby objęcie jednym systemem normatywnym także obecnych cywilnoprawnych stosunków tzw. parapracowników, a nawet stosunków służbowych. Przy takim założeniu prawo pracy miałoby nie jedną - jak obecnie - lecz aż trzy centralne konstrukcje prawne, wokół których integrowane byłyby poszczególne części tego prawa. Systematyka tak rozumianego prawa pracy w modelowym ujęciu przybrałaby postać czterech części - ogólnej, mającej zastosowanie do ogółu stosunków prawnych objętych tą gałęzią prawa, oraz trzech osobnych działów regulujących poszczególne rodzaje tych stosunków. W istocie tak pojmowane prawo pracy uległoby przekształceniu $\mathrm{w}$ prawo zatrudnienia. Cechą charakterystyczną takiego prawa byłaby wspólna aksjologia i wspólne konstrukcje podstawowe, natomiast w niezbędnym zakresie mogłyby zostać utrzymane odrębności statusu osób zatrudnionych w ramach dotychczasowych stosunków pracy, stosunków cywilnoprawnych oraz stosunków służbowych.

7. Jeśli słuszne jest założenie o koniecznych zmianach systemu prawa regulującego stosunki zatrudnienia, to $\mathrm{z}$ pewnością zarysowany $\mathrm{w}$ niniejszym opracowaniu dylemat - prawo pracy (monocentryczne) czy prawo zatrudnienia (policentryczne) - będzie musiał być rozstrzygnięty $\mathrm{w}$ nieodległej przyszłości. Dotychczasowa ewolucja systemu prawnego zdaje się raczej przemawiać na rzecz prawa zatrudnienia, a więc koncepcji policentrycznej. Oznaczałoby to stopniowe włączanie do prawa pracy kolejnych grup zatrudnionych. Nowe, zmienione prawo pracy (a właściwie prawo zatrudnienia) objęłoby pewnym podstawowym standardem ochrony wszystkich zatrudnionych, natomiast w dalszym ciaggu zachowane zostałyby w niezbędnym zakresie odrębności ich statusu prawnego. De lege lata nie ma wyraźnych podstaw do kwalifikowania naszego systemu prawa pracy jako policentrycznego, niemniej w doktrynie już od dawna postuluje się ten kierunek rozwoju ${ }^{12}$.

\section{Bibliografia}

Jaśkiewicz W., Jackowiak C., Piotrowski W., Prawo pracy w zarysie, Warszawa 1985.

Jończyk J., Prawo pracy, Warszawa 1992.

Kuczyński T., Właściwość sądu administracyjnego w sprawach stosunków stużbowych, Wrocław 2000.

Podgórska-Rakiel E., Szczególna ochrona trwałości zatrudnienia działaczy związkowych pozostajacych w zatrudnieniu cywilnoprawnym - uwagi de lege lata $i$ de lege ferenda, [w:] Zwiazkowe przedstawicielstwo pracowników zakładu pracy, red. Z. Hajn, Warszawa 2012.

${ }_{12}$ Zob. np. J. Jończyk, Prawo pracy, Warszawa 1992, s. 15; W. Sanetra, Prawo pracy, Białystok 1994, s. 28 i 32; T. Kuczyński, Właściwość sądu administracyjnego w sprawach stosunków stużbowych, Wrocław 2000, s. 50 i nast. 
Rifkin J., Koniec pracy. Schyłek siły roboczej na świecie i początek ery postrynkowej, Wrocław 2003.

Salwa Z., Prawo pracy i ubezpieczeń społecznych, Warszawa 1996.

Salwa Z., Szubert W., Święcicki M., Podstawowe problemy prawa pracy, Warszawa 1957.

Sānchez Morón M., Derecho de la función pública, Madrid 2013.

Sanetra W., Prawo pracy, Białystok 1994.

Sobczyk A., Prawo pracy w świetle Konstytucji RP, t. I, Teoria publicznego i prywatnego indywidualnego prawa pracy, Warszawa 2013.

Supiot A., Beyond Employment. Changes in Work and the Future of Labour Law in Europe, Oxford 2001.

Szubert W., Zarys prawa pracy, Warszawa 1980.

Tomaszewska M., Prawo integracji stosunku pracy. Między jednościa a różnorodnościa, Gdańsk 2011.

Zieliński T., Prawo pracy. Zarys systemu, t. I, Warszawa-Kraków 1986.

\section{Monocentric versus Polycentric Labour Law}

\section{Summary}

Labour law is of monocentric character currently. It means that only one of the legal relations' types is located in the center of this branch of law. Traditional labour law is defined as a complex of legal rules regulating social relations of labour and other relations strictly connected with relations of labour. Thus, a labour relation is a concept which integrates labour law. However, employment beyond labour relations, in particular on the basis of civil contracts, has become more and more popular in recent years. A labour relation, alongside with labour law, loses its dominant position within the employment system, for the benefit in particular of civil relations. On the other hand, administrative law plays a significant role in public sector, regulating service relations of the state servants. We might consider three basic employment regimes nowadays - labour law, civil law and administrative law. Hence, the question about the future of labour law arises. It seems that one of scenarios might be approaching of above mentioned employment regimes, which are regulated by different branches of law nowadays. If we agree that persons employed under different legal regimes shall have similar legal status as a rule, it makes a concept of multicentric character of labour law open. Regarding that assumption, labour law would have not the one, as currently, but three legal frameworks, which would integrate particular parts of this branch of law. It would not actually be a labour law, but employment law. 